\title{
Spatial and temporal variation in grazing damage by the gastropod Lacuna vincta in Nova Scotian kelp beds
}

\author{
Kira A. Krumhansl*, Robert E. Scheibling \\ Department of Biology, Dalhousie University, Halifax, Nova Scotia B3H 4J1, Canada
}

\begin{abstract}
Population increases of the gastropod Lacuna vincta have been associated with significant damage to kelp blades and decreases in kelp biomass in subtidal kelp beds off Nova Scotia, Canada. We measured the total level and along-blade distribution of grazing damage by Lacuna vincta on the dominant kelp species at 5 sites in Nova Scotia, Canada, over a 15 mo period. Grazing was typically low or absent in the basal regions of blades, consistent with seasonal fluctuations in growth and physical properties of blade tissues. Grazing was largely concentrated in middle and distal sections, although this distribution varied with site exposure and over time. The cover of the invasive bryozoan Membranipora membranacea on the surface of kelp blades did not have a strong effect on grazing by L. vincta. The total level of grazing damage (max. $1 \%$ of blade area for Saccharina longicruris and $1.5 \%$ for Laminaria digitata) varied seasonally, with peaks in September at some sites. Spatial variation was driven in part by a negative relationship with site exposure. In a field experiment, simulated grazing damage that exceeded a threshold value of 0.5 to $1.0 \%$ of blade area caused a significant increase in blade loss during a period of heavy wave action due to a passing hurricane. Our results show that direct reductions in kelp biomass through grazing by $L$. vincta are relatively small, but can indirectly lead to significant losses of kelp biomass during large wave events.
\end{abstract}

KEY WORDS: Lacuna vincta $\cdot$ Laminaria digitata $\cdot$ Saccharina longicruris · Grazing · Mesograzers · Kelp beds $\cdot$ Detritus $\cdot$ Membranipora membranacea

Resale or republication not permitted without written consent of the publisher

\section{INTRODUCTION}

Mesograzers, such as small snails and crustaceans (Brawley 1992), can have large direct effects on benthic community organization by influencing the dynamics of early succession (Scheibling et al. 2009), reducing macrophyte biomass (Johnson \& Mann 1986, Chenelot \& Konar 2007), and cycling nutrients through consumption of detrital material (Robertson \& Lucas 1983). Tissue damage by mesograzers can also increase the susceptibility of macrophytes to other forms of disturbance, such as breakage or dislodgement by hydrodynamic forces (Duggins et al. 2001, Krumhansl \& Scheibling 2011). These indirect effects may have important consequences for the structure and dynamics of both the local community and adjacent communities that depend on allochthonous inputs in the form of macrophyte detritus (Bustamante et al. 1995, Vetter 1995).

In kelp beds, the rate of consumption of macroalgal biomass by snails and other mesograzers is small relative to that of large and abundant grazers such as sea urchins (Lawrence 1975, Harrold \& Pearse 1987). However, in areas where sea urchins are rare or absent, mesograzers may be the dominant herbivores (Kangas et al. 1982, Johnson \& Mann 1986, Duggins et al. 2001, Chenelot \& Konar 2007, Scheibling et al. 2009). In the northwest Atlantic, the gastropod Lacu- 
na vincta is the only mesograzer known to consume macroscopic kelp sporophytes (Brady-Campbell et al. 1984, Johnson \& Mann 1986). On the Atlantic coast of Nova Scotia, L. vincta is seasonally abundant in kelp beds, with peak densities (up to 2000 individuals $\mathrm{m}^{-2}$ ) during recruitment in February, and seasonal lows between August and October (Johnson \& Mann 1986). L. vincta preferentially grazes kelps (Chavanich \& Harris 2002), creating perforations or superficial excavations on the surface of blades. Johnson \& Mann (1986) estimated that the cumulative effect of grazing by $L$. vincta was a removal of only $0.05 \%$ of standing blade biomass of Saccharina (=Laminaria) longicruris in a kelp bed in St. Margarets Bay, Nova Scotia. However, population explosions of L. vincta in the Gulf of Maine have been associated with high levels of damage to kelp blades and canopy loss (Fralick et al. 1974). Krumhansl \& Scheibling (2011) linked variation in the rate of kelp blade fragmentation and erosion to damage along the distal ends of blades, suggesting that grazing by L. vincta can indirectly decrease kelp biomass and increase detrital production.

Spatial and temporal variation in grazing damage to kelps and other macroalgae in shallow marine habitats is caused by various abiotic and biotic factors. Wave exposure generally has a negative effect on grazing rate (Duggins et al. 2001, Vanderklift et al. 2009, Taylor \& Schiel 2010, but see also Robles \& Robb 1993), although the underlying mechanisms and magnitude of this effect can vary among habitats. Structural properties and nutritional quality of blades can also vary seasonally with changes in water temperature (Sjotun et al. 1996, Abdullah \& Fredriksen 2004). For example, warming temperatures can increase grazing damage by accelerating degradation of older tissues at the distal ends of blades (Rothausier et al. 2009), which reduces toughness and increases palatability (Molis et al. 2010).

The process of blade elongation, and variation in chemical or structural characteristics of tissues along kelp blades may influence the distribution of grazing damage on individual thalli. As new blade tissue is produced at the basal meristem, existing tissue continually progresses towards the distal end of the blade, where it fragments or gradually erodes. If grazing occurred randomly across the blade surface, we would expect an increase in the amount of grazerdamaged tissue with distance from the meristem and period of exposure to grazers. Polyphenolic content is highest near the meristem, which has been linked to low grazing rates in the basal region (Johnson \& Mann 1986).
Encrustation of kelp blades by the invasive epiphytic bryozoan Membranipora membranacea also may influence the distribution and intensity of grazing by Lacuna vincta. Blade encrustation peaks in September and October ( 100\% cover on some kelp blades) and declines to extremely low levels from February to May (Scheibling \& Gagnon 2009, Krumhansl \& Scheibling 2011). L. vincta is assumed to be strictly herbivorous (Iyengar \& Harvell 2002), and $M$. membranacea may limit grazing by preempting space on blade surfaces. However, a positive association between cover of $M$. membranacea and density of $L$. vincta has been observed in the Gulf of Maine (Chavanich \& Harris 2000).

In the present study, we examine spatial and seasonal patterns in grazing damage by Lacuna vincta along blades of Saccharina longicruris and Laminaria digitata over 15 mo at 5 sites varying in wave exposure and cover of Membranipora membranacea. Grazing damage provides a time-integrated measure of the intensity and distribution of grazing that enables us to test the following predictions: (1) damage along kelp blades will be lowest near the base and highest at the distal end; (2) damage will decrease with the cover of M. membranacea on kelp blades; and (3) damage will be negatively related to wave action and positively related to temperature. We also experimentally examine the indirect effect of grazing damage on kelp blade breakage by simulating different levels of grazing damage on $S$. longicruris in field experiments during moderate to heavy wave conditions.

\section{MATERIALS AND METHODS}

\section{Grazing damage measurements}

As part of a broader study of kelp production and erosion rates (Krumhansl \& Scheibling 2011), we measured grazing damage on kelps at 5 sites of varying wave exposure along the Atlantic coast of Nova Scotia: Duncan's Cove Exposed, Duncan's Cove Protected, Splitnose Point, The Lodge, and Cranberry Cove. The kelps Saccharina longicruris and Laminaria digitata occur in monospecific or mixed stands as the dominant canopy-forming macroalgae at all sites. The morphology of $S$. longicruris is characterized by a single, strap-like blade with ruffled margins. L. digitata has a broad blade that splits into 'digits' near the distal end. Measurements were taken on kelps growing on substrates ranging from small boulders to rock ledges at 5 to $7 \mathrm{~m}$ depth. For detailed site descriptions, see Krumhansl \& Scheibling (2011). 
Grazing damage was measured on 10 to $15 \mathrm{kelp}$ thalli, > $5 \mathrm{~cm}$ blade length, that were haphazardly collected using SCUBA at 6 times over a 15 mo period (July, September, November 2008; February, May, September 2009). Measurements were obtained at all sites in July, September (2008 and 2009), and May. In November, measurements were taken at The Lodge and Splitnose Point because the invasive bryozoan Membranipora membranacea occurs in high abundance during this period at these sites only. In February, logistical constraints limited our measurements to Duncan's Cove Protected, Splitnose Point, and Cranberry Cove. Grazing damage on thalli of Laminaria digitata was not measured at Cranberry Cove (all sampling periods) or Duncan's Cove Protected (July 2008) because this species was not abundant at these sites or seasons.

To measure grazing damage, thalli were pressed between 2 pieces of Plexiglass and photographed. We characterized grazing damage as perforations (holes) or superficial excavations of the blade (Fig. 1A,B). Excavations were difficult to delineate in photographs and have little effect on blade strength (Krumhansl et al. 2011); therefore, we measured perforations only. The area grazed in each of 3 equal sections of blade by length was measured by manually outlining grazed holes in ImageJ (NIH). This was divided by the area of the respective blade section to estimate \% of blade area grazed in the base, middle, and distal regions of blades. The area grazed in each section was then divided by the total area grazed on a blade to generate the \% of total grazed area in each section. The total area of grazed holes in all sections was divided by the total blade area to estimate the \% of blade area grazed.

Grazing damage was measured in relation to site exposure, temperature, and cover of Membranipora membranacea. The relative exposure of each site was determined by calculating a relative exposure index (REI; modified from Keddy 1982) using fetch and wind data (directional average wind speed and probability) for a $3 \mathrm{wk}$ period before each measurement (REI values presented in Krumhansl \& Scheibling 2011). This index uses wind data for a specific time period, and therefore index values vary both seasonally as well as spatially. Previous studies comparing wave-based exposure indices to those based on fetch have found good correlation between the two, suggesting that the latter can appropriately be used to approximate wave exposure at a particular site (Hill et al. 2010). Temperature was recorded using temperature loggers (Onset StowAway Tidbits or HOBO Pendant Data Loggers), and averaged for
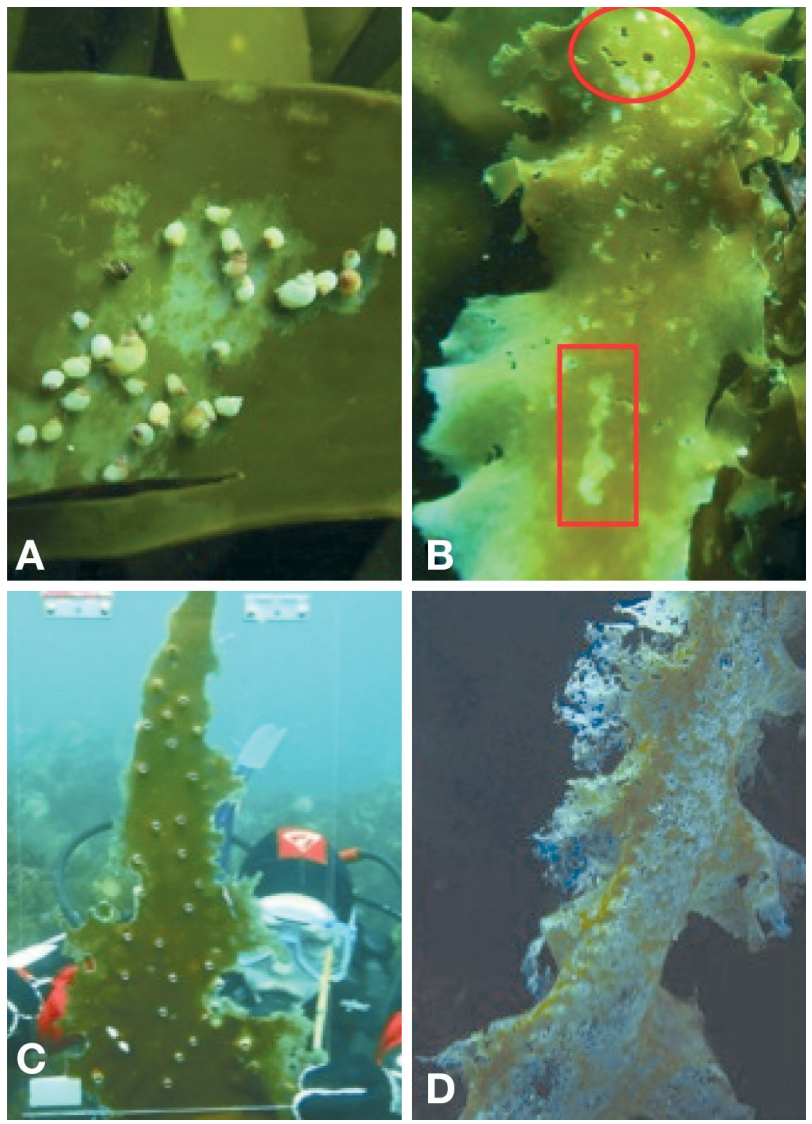

Fig. 1. (A) Lacuna vincta actively grazing Laminaria digitata. (B) Grazed perforations (circled), and excavations (inside rectangle) on a blade of Saccharina longicruris; (C) applying the 30 -hole simulated grazing treatment to the distal $45 \mathrm{~cm}$ of a blade of $S$. longicruris, pressed between 2 pieces of Plexiglass; (D) a heavily grazed blade of $S$. longicruris at The Lodge in September 2010. Photographs by R. Scheibling

$3 \mathrm{wk}$ before each sampling period for analysis (Krumhansl \& Scheibling 2011). Temperature data were not available for the July 2008 sampling period. Percentage cover of $M$. membranacea was measured by photographing each collected thallus and outlining colonies of $M$. membranacea. Tracings were then photographed and the area measured using image analysis. The area covered by $M$. membranacea was divided by total blade area to measure the \% of blade covered by the bryozoan for each thallus.

\section{Simulated grazing experiment}

The effect of grazing damage on rates of blade fragmentation was examined experimentally on Saccharina longicruris. The experiment was conducted in August and September 2009 to correspond with the 
seasonal occurrence of storms and hurricanes, as well as a seasonal peak in kelp erosion rates (Krumhansl \& Scheibling 2011). Artificial holes were punched in the distal ends of blades of S. longicruris at The Lodge to mimic grazing damage by Lacuna vincta. This was done by sandwiching the thallus in a hinged Plexiglass folder with imbedded sections of copper tubing that punctured the thallus as the folder was closed (Fig. 1C). Three levels of simulated grazing damage were applied to reflect the observed range of area grazed $\left(0\right.$ to $25 \mathrm{~cm}^{2}, 0.0$ to $1.4 \%$ of blade area) on the distal end of kelp blades, and average size of perforations caused by grazing $\left(0.32 \mathrm{~cm}^{2}\right.$ $\pm 0.08 \mathrm{SE}, \mathrm{n}=57$ ) on kelps at The Lodge in September 2008. Treatments consisted of 10 ('low grazing damage'), 30 ('moderate grazing damage'), and 60 ('high grazing damage') holes (i.e. losses of blade area of $3.2,9.6,19.2 \mathrm{~cm}^{2}$, respectively) randomly distributed in a triangular area encompassing the distal $45 \mathrm{~cm}$ of blade, and a control with no artificial holes. Four experimental blocks were set parallel to the shore at a depth of 5 to $6 \mathrm{~m}$. Eight kelps 120 to $250 \mathrm{~cm}$ in blade length with little grazing damage were selected in each block, and 2 individuals were randomly assigned to each of the treatments or control. A numbered tag was affixed to the holdfast of each experimental thallus to enable relocation.

Rate of blade breakage was measured during 2 experimental runs, beginning on 7 and 27 August and spanning 2 successive storm events varying in intensity. Breakage of each blade was measured using a modified 'hole punch' method (see Krumhansl \& Scheibling 2011 for details). A hole was punched $10 \mathrm{~cm}$ directly above the base of the blade (where the blade is twice the width of the stipe) using a sharpened piece of copper tubing, and total blade length was measured. After $3 \mathrm{wk}$, each individual was collected and returned to the lab. Growth hole position (as distance from the base of the blade) and final blade length were measured. The loss in length due to breakage, accounting for growth, was then calculated and divided by the total number of days over which the measurements were taken. This generated an estimate of rate of breakage in $\mathrm{cm} \mathrm{d}^{-1}$. The distal 30 to $50 \mathrm{~cm}$ of each thallus (depending on the total blade length) was dried at $60^{\circ} \mathrm{C}$ for $48 \mathrm{~h}$, and dry weight was measured. Dry weight was divided by the length of the segment to determine the dry weight biomass $\left(\mathrm{g} \mathrm{cm}^{-1}\right)$ of the distal end of the blade. This measurement was then used to convert rate of blade breakage in $\mathrm{cm} \mathrm{d}^{-1}$ to $\mathrm{g} \mathrm{d}^{-1}$.

We calculated the mean and maximum significant wave height, defined as the mean of the largest one third of waves measured, for each experimental trial from data recorded at a meteorological buoy located at the mouth of Halifax Harbour (National Climate Data and Information Archive, www.meds-sdmm.dfompo.gc.ca, buoy ID\# C44258, $44^{\circ} 30^{\prime} \mathrm{N}, 63^{\circ} 24^{\prime} \mathrm{W}$ ). Wave data were not available from 12 August to 19 August 2009 due to equipment malfunction.

\section{Statistical analysis}

To examine seasonal and spatial variation in the distribution of grazing damage, we analyzed the effects of site, season, and location on blade on the \% of thallus area grazed by a factorial ANOVA, using a splitplot design. To achieve an orthogonal design, only time periods where sampling occurred at all sites were included in the analysis (Saccharina longicruris: July and September 2008, May and September 2009; Laminaria digitata: September 2008, May and September 2009). Main-plot factors were site and time (both fixed factors), while the sub-plot factor was location on the blade (fixed factor) of each individual (random factor, nested within site and time). Data were not normally distributed (Shapiro-Wilks test, p < 0.001 ) and variances were heterogeneous (Levene's test, $\mathrm{p}<0.001$ ). Arcsine transformation of the $\%$ of thallus area grazed yielded similar results for tests of these assumptions of ANOVA; therefore we performed the analysis on untransformed data. Variance heterogeneity can inflate the Type I error rate; to adjust for this possibility, we use $\alpha=0.01$ in this analysis.

We used an information-theoretic approach to examine factors that influence the extent of total grazing damage on thalli at a site scale. The \% of total blade area grazed was averaged across individuals for each site and season by species. Secondorder, bias-corrected Akaike's information criterion (AICc), the values of the maximized log-likelihood function, and model probabilities were used to assess the relative strength of possible models containing temperature and/or site exposure (REI) in explaining variation in the \% of total area grazed on thalli. To further assess the relative importance of each individual factor, the model probabilities of all models containing each individual factor were summed. Factors with higher summed model probabilities are considered to be more important than factors with lower values (Anderson 2008). Examination of tolerance values indicated that variables were not collinear (tolerance $<0.60$; van den Poel \& Lariviere 2004).

The effect of Membranipora membranacea on total grazing damage on thalli was examined for individu- 
als of Saccharina longicruris and Laminaria digitata at Splitnose Point and The Lodge during periods of peak encrustation (September and November 2008, and September 2009). Analysis of Covariance (ANCOVA) indicated that the slopes of the relationship between the \% of blade covered by M. membranacea and total \% blade area grazed (where these were significant) did not significantly differ between sampling periods within each site $(p>0.05)$. Therefore, data were pooled across sampling periods at each site, and linear regression was used to detect significant relationships between bryozoan cover and snail grazing damage. Individual kelps with no grazing damage were excluded from these analyses. Data were arcsine transformed where necessary to meet the assumptions of bivariate normality (ShapiroWilks test, $\mathrm{p}>0.05$ ) and homogeneity of variance (Breusch-Pagan test, $\mathrm{p}>0.05$ ).

We used factorial ANOVA to examine the effect of experimental trial (fixed factor), treatment (fixed factor), and block (random factor) on erosion rates in the artificial grazing experiment. Experimental trial was considered fixed because of the deliberate timing of the trials in advance of specific storm events. The block effect was not significant $(p=0.49)$, so data were pooled across blocks for further analysis (Underwood 1997). Post hoc comparisons between treatment levels were performed using Tukey's HSD tests. All data were $\log (x+1)$ transformed to meet the assumptions of normality (Shapiro-Wilks test, $\mathrm{p}>$ 0.05 ) and homogeneity of variance (Bartlett's test, $p>$ 0.05 ). All statistical analyses were performed using JMP (version 5.1, SAS Institute).

\section{RESULTS}

\section{Distribution of grazing damage along individual kelp thalli}

Grazing damage did not occur evenly along the length of blades on Saccharina longicruris or Laminaria digitata (Fig. 2). A highly significant 3-way interaction between site, time, and location on blade for both species indicates that temporal variation in the $\%$ of area grazed in each section of blade varied across sites (Table 1). For both species of kelp, grazing was generally highest in the middle and distal section of blades, and lowest in the basal section, except at Splitnose Point where damage was low or absent in the middle of blades during all sampling periods except November (Fig. 2). Damage in the basal section was lowest from November to May and

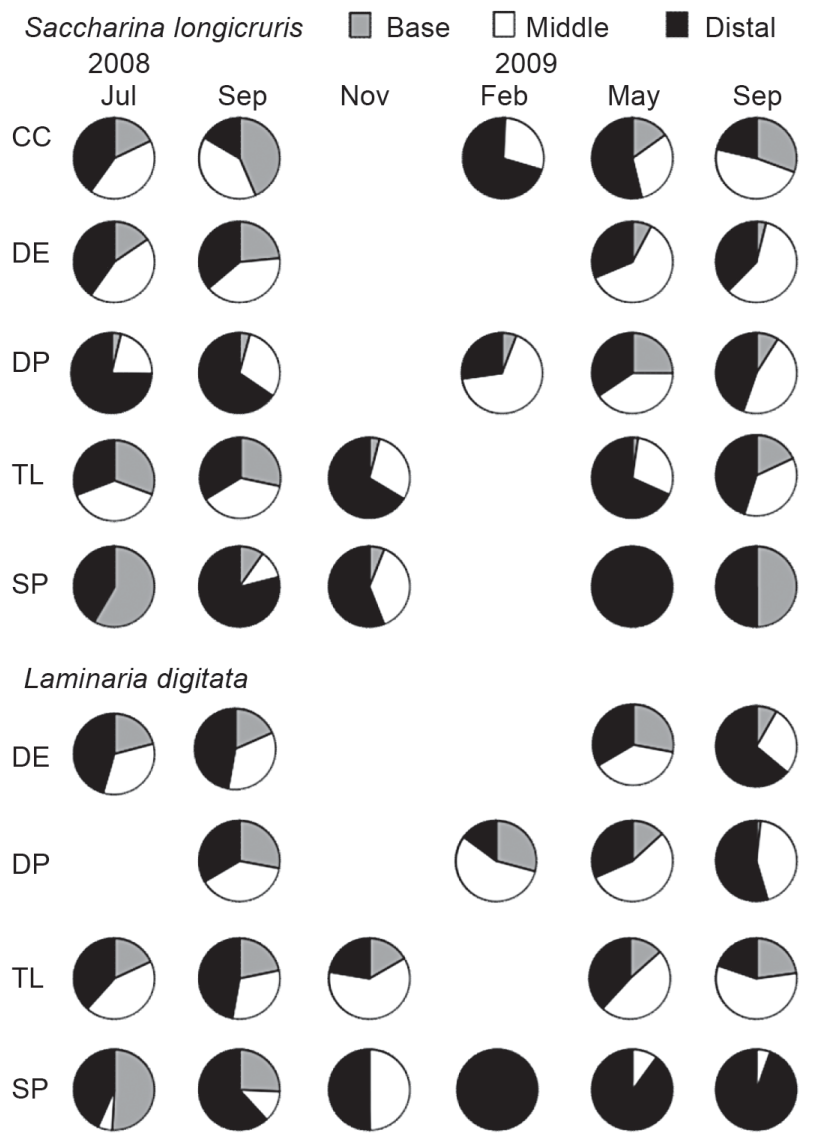

Fig. 2. \% of total grazed area in the basal, middle, and distal sections of blades of Saccharina longicruris and Laminaria digitata at 5 sites: Cranberry Cove (CC), Duncan's Cove Exposed (DE), Duncan's Cove Protected (DP), The Lodge (TL), Splitnose Point (SP) in all sampling months

highest in July and September at all sites except Duncan's Cove Protected and Splitnose Point (Fig. 2). At Duncan's Cove Protected, grazing in the basal sections of L. digitata remained high from September 2008 to February 2009, but decreased from May to September 2009. In contrast, grazing in the basal sections of $S$. longicruris at this site was low during all sampling periods except May. At Splitnose Point, damage in the basal sections of $L$. digitata was absent in September 2009 (S. longicruris only). Damage was more heavily concentrated in the distal region of blades at Splitnose Point than at other sites for both species during all sampling periods (Fig. 2).

\section{Seasonal and spatial trends in grazing intensity}

The $\%$ of total blade area lost through grazing by Lacuna vincta ranged from 0.00 to $1.25 \%$ for Saccharina longicruris, and 0.00 to $1.50 \%$ for Laminaria dig- 
Table 1. Results of split-plot analysis of variance of the effect of site, season, and location on blade on total percentage of blade area grazed by snails on Saccharina longicruris and Laminaria digitata. Main plot factors include site and season, and sub-plot factors include location on blade

\begin{tabular}{|lrcr|}
\hline Factor & df & $F$ & $\mathrm{p}$ \\
\hline Saccharina longicruris & & & \\
Site & 4 & 35.2 & $<0.001$ \\
Season & 3 & 1.06 & 0.367 \\
Season $\times$ Site & 12 & 36.7 & $<0.001$ \\
Main-plot error & 240 & & \\
Location & 2 & 19.5 & $<0.001$ \\
Location $\times$ Site & 8 & 3.53 & $<0.001$ \\
Location $\times$ Season & 6 & 3.90 & 0.001 \\
Location $\times$ Site $\times$ Season & 24 & 3.08 & $<0.001$ \\
Sub-plot error & 480 & & \\
Laminaria digitata & & & \\
Site & 3 & 66.4 & $<0.001$ \\
Season & 2 & 13.1 & $<0.001$ \\
Season $\times$ Site & 6 & 14.5 & $<0.001$ \\
Main-plot error & 162 & & \\
Location & 2 & 83.9 & $<0.001$ \\
Location $\times$ Site & 6 & 30.8 & $<0.001$ \\
Location $\times$ Season & 4 & 2.59 & 0.037 \\
Location $\times$ Site $\times$ Season & 12 & 3.55 & $<0.001$ \\
Sub-plot error & 324 & & \\
\hline
\end{tabular}

itata (Fig. 3). Seasonal trends in grazing damage on both $S$. longicruris and L. digitata varied between sites, as indicated by a significant interaction between site and time for both species (Fig. 3, Table 1). Some seasonality in grazing damage on $S$. longicruris was evident at The Lodge, where the highest rates were observed in September 2008 and 2009 (0.79 to $0.93 \%)$, and the lowest rates were observed in November 2008 and May 2009 (0.25 to $0.36 \%$ in both months; Fig. 3). Grazing damage on L. digitata also increased from July to September 2008 at this site ( 0.37 to $0.60 \%)$, but remained high in November

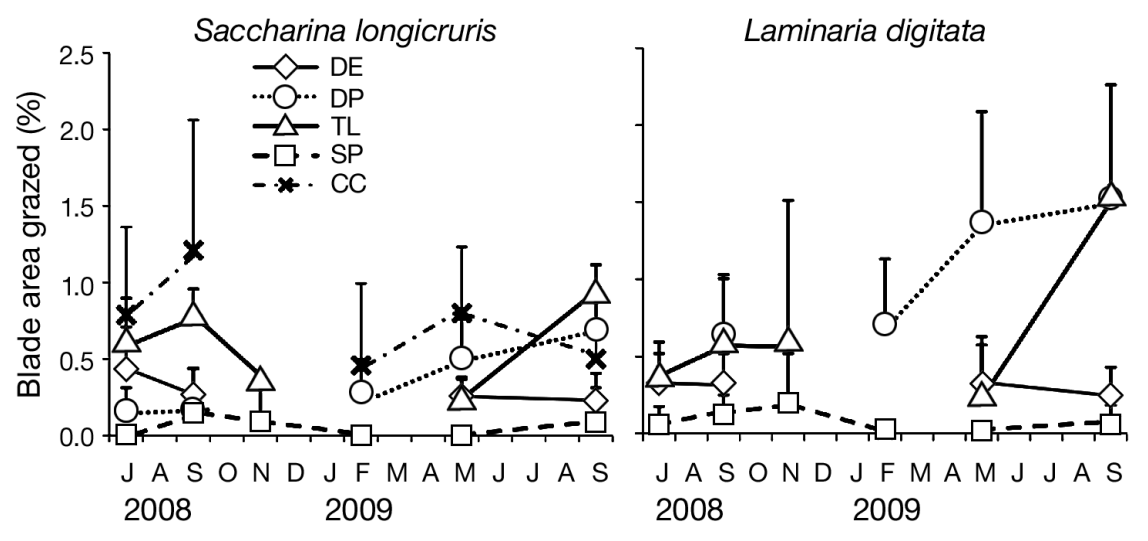

Fig. 3. \% of total blade area grazed on Saccharina longicruris and Laminaria digitata over 15 mo at 5 sites. Data are mean +1 SD for 10 to 15 thalli at each sampling period. See Fig. 2 for abbreviations
2008. A large increase in grazing damage on this species was then observed in September 2009 (1.50\%). This was similar to patterns observed at Duncan's Cove Protected, where grazing damage increased over the study on both $S$. longicruris $(0.16$ to $0.70 \%$ ) and $L$. digitata ( 0.70 to $1.50 \%$ ), peaking in September 2009. Grazing was consistently lowest of all sites and showed little temporal variation at Splitnose Point and Duncan's Cove Exposed for S. longicruris (Splitnose Point: 0 to $0.14 \%$, Duncan's Cove Exposed: 0.22 to $0.43 \%$ ) and L. digitata (Splitnose Point: 0.00 to $0.19 \%$, Duncan's Cove Exposed: 0.24 to $0.37 \%$ ). Grazing was consistently highest at Cranberry Cove for S. longicruris (0.46 to $1.21 \%$ ), peaking in September 2008 and May 2009.

The total \% of blade encrusted by Membranipora membranacea had a marginally significant positive effect on blade area grazed for Saccharina longicruris at Splitnose Point (slope $=0.02$ ), but this effect was not observed at The Lodge (Fig. 4). There was no significant relationship between bryozoan cover and total \% of blade area grazed for Laminaria digitata at either Splitnose Point or The Lodge.

\section{Relationship with physical variables}

REI was consistently highest at Splitnose Point (2346 to 4375), intermediate at Duncan's Cove Exposed (239 to 1062), The Lodge (535 to 1044), and Cranberry Cove (553 to 1313), and lowest at Duncan's Cove Protected (1 to 6). Temperature and site exposure were factors present in the best model explaining variation in grazing damage on blades of Saccharina longicruris, although the overall fit of this model was low $\left(R^{2}=0.24\right.$; Table 2$)$. Site exposure (negatively related) had a higher sum of model probabilities $(0.88)$ than temperature (positively related, 0.58 ; Table 3), and explained more of the variation in grazing damage (Table 2). Site exposure (negatively related) was the only factor present in the top model explaining variation in grazing damage on Laminaria digitata, with a greater overall fit $\left(\mathrm{R}^{2}=0.34\right)$ than the model for $S$. longicruris (Tables 2 \& 3 ) and a high sum of model probabilities (0.98). Temperature was likely unrelated to grazing damage for this species, indicated by low model likelihood, $\mathrm{R}^{2}$ value (Table 2 ), and sum of model probabilities $(0.30)$. 


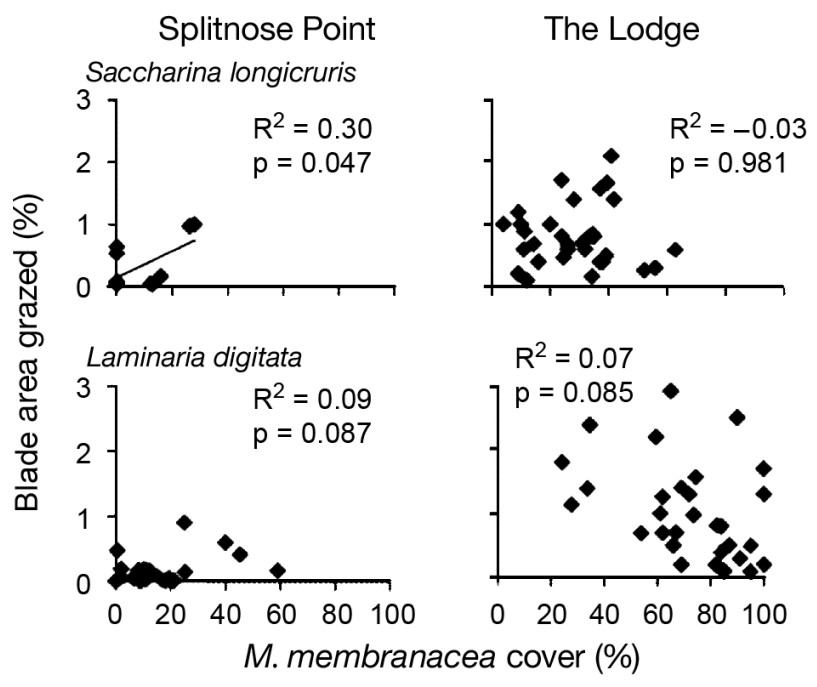

Fig. 4. Relationship between total \% of blade area grazed by Lacuna vincta on Saccharina longicruris and Laminaria digitata and \% of blade area covered by Membranipora membranacea for September and November 2008 and September 2009 at Splitnose Point and The Lodge. $\mathrm{R}^{2}$ and $\mathrm{p}$ values from linear regressions are indicated on each figure. A line is fitted where significant results were obtained
Table 3. Coefficient estimates and SEs for factors in the top model according to 2nd-order bias-corrected AIC explaining variation in the \% of thallus area grazed for Saccharina longicruris and Laminaria digitata. Factors included are site exposure (Exp) and temperature $\left(\mathrm{Temp},{ }^{\circ} \mathrm{C}\right)$

\begin{tabular}{|lccc|}
\hline Species & Model & Estimate & SE \\
\hline Saccharina longicruris & Exp & $-1.0 \times 10^{-4}$ & $<0.01$ \\
& Temp & $2.0 \times 10^{-2}$ & $<0.01$ \\
Laminaria digitata & Exp & $-1.0 \times 10^{-4}$ & $<0.01$ \\
\hline
\end{tabular}

pieces of blade tissue. It was evident that tears in the blade tissue typically began at a simulated grazing hole.

Wave conditions differed markedly between trials (Fig. 5B). During Trial 1, Hurricane Bill passed along the Atlantic coast of Nova Scotia as a Category 1 storm on 23 August 2009, generating a maximum significant wave height of $9.0 \mathrm{~m}$. During Trial 2, a weak tropical cyclone (Danny) generated a maximum significant wave height of $3.5 \mathrm{~m}$ on 30 August 2009.

\section{Simulated grazing experiment}

Rate of blade breakage of kelps increased significantly with the level of simulated grazing damage in the first experimental trial, but not in the second (Fig. 5A, Table 4). In Trial 1, erosion increased significantly between low and moderate damage (10 vs. 30 hole) treatments. During Trial 2, erosion in all treatments was minimal and similar to that measured in the control and low damage treatments in Trial 1. Breakage usually occurred as fragmentation of large

Table 2. Akaike's Information Criteria (AIC) for all models containing site exposure (Exp) and temperature $\left(\mathrm{Temp},{ }^{\circ} \mathrm{C}\right)$ as factors explaining variation in percentage of blade area grazed for Saccharina longicruris and Laminaria digitata. Also shown are the 2nd-order bias-corrected Akaike's Information Criteria $\left(\mathrm{AIC}_{\mathrm{c}}\right)$, the difference between the minimum $\mathrm{AIC}_{\mathrm{c}}$ and the $\mathrm{AIC}_{\mathrm{C}}$ of each model $\left(\Delta \mathrm{AIC}_{\mathrm{c}}\right)$, the log likelihood function $(\mathrm{LL})$, the model probability $\left(\mathrm{w}_{\mathrm{i}}\right)$, and the $\mathrm{R}^{2}$ value of each model

\begin{tabular}{|lccccccc|}
\hline Model & AIC & $\mathrm{AIC}_{\mathrm{c}}$ & $\mathrm{n}$ & $\Delta \mathrm{AIC}_{\mathrm{c}}$ & $\mathrm{LL}$ & $\mathrm{w}_{\mathrm{i}}$ & $\mathrm{R}^{2}$ \\
\hline \multicolumn{2}{l}{ Saccharina longicruris } & & & & & & \\
Temp $\times$ Exp & -230.9 & -230.2 & 20 & 0.00 & 117.47 & 0.465 & 0.24 \\
Exp & -230.3 & -230.0 & 20 & 0.21 & 116.13 & 0.418 & 0.18 \\
Temp & -227.7 & -227.5 & 20 & 2.75 & 114.85 & 0.117 & 0.11 \\
& & & & & & & \\
Laminaria digitata & & & & & & \\
Exp & -173.5 & -173.2 & 16 & 0.00 & 87.74 & 0.698 & 0.34 \\
Temp $\times$ Exp & -171.7 & -171.4 & 16 & 1.8 & 86.85 & 0.288 & 0.32 \\
Temp & -165.5 & -165.5 & 16 & 7.7 & 83.9 & 0.015 & 0.00 \\
\end{tabular}

\section{DISCUSSION}

Grazing damage was not evenly distributed along the length of blades for either Saccharina longicruris or Laminaria digitata, and varied spatially and seasonally. As we predicted, grazing damage was generally lowest in the basal section of blades, especially during the seasonal peak in kelp growth between February and May (Mann 1972, Chapman \& Craigie 1977, Krumhansl \& Scheibling 2011). This may be explained by the lower exposure time of rapidly growing tissue to grazing, or by the presence of polyphenolics, which are known to peak during periods of rapid growth (Johnson \& Mann 1986, Abdullah \& Fredriksen 2004). Increases in grazing damage in the basal part of blades in July and September corresponded to seasonal reductions in growth rate and associated production of polyphenolics (Mann 1972, Abdullah \& Fredriksen 2004, Krumhansl \& Scheibling 2011). Also as predicted, grazing was often greatest in the distal sections of blades, which was likely related to increased exposure time to grazing as well as greater palatability and decreased toughness of blade material 

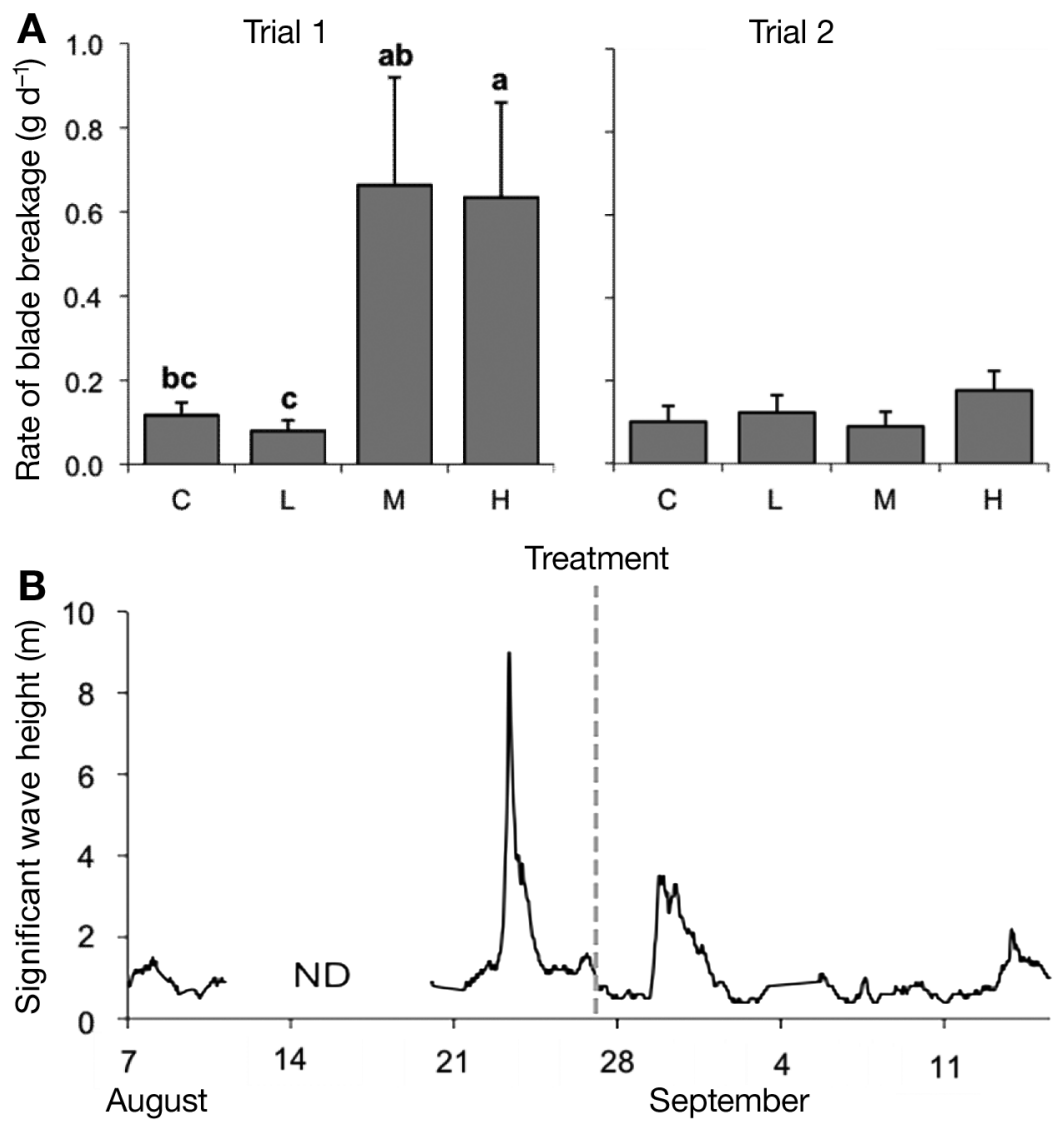

Fig. 5. (A) Rate of blade breakage of Saccharina longicruris at 4 levels of simulated grazing damage: control $(\mathrm{C})$, low $(\mathrm{L})$, moderate $(\mathrm{M})$, and high $(\mathrm{H})(0,10$, 30,60 artificial holes per distal $45 \mathrm{~cm}$ of blade, respectively) in 2 experimental trials beginning on 7 and 27 August 2009, respectively. Data are mean + 1 SE for 6 to 8 thalli in each treatment during each trial. Letters indicate statistically significant groupings. (B) Significant wave height recorded hourly during both trials. ND indicates time period during which wave data were unavailable. Dashed line: sequential trials

Table 4. ANOVA of the effect of simulated grazing treatment on rate of blade breakage $\left(\mathrm{g} \mathrm{d}^{-1}\right)$ of Saccharina longicruris in 2 experimental trials, including a Tukey's HSD test for pairwise comparisons between treatment levels

\begin{tabular}{|lcccc|}
\hline Factor & df & $F$ & $\mathrm{p}$ & Pairwise \\
\hline Treatment & 3 & 7.94 & $<0.001$ & \\
Trial & 1 & 11.8 & 0.001 & \\
Treatment $\times$ Trial & 3 & 4.73 & 0.006 & Trial $1: 0=10<30<60$ \\
Error & 47 & & & Trial 2: $0=10=30=60$ \\
\hline
\end{tabular}

associated with the degradation of aged tissues (Norderhaug et al. 2003, Molis et al. 2010).

We found no evidence to support our prediction that encrustation by the invasive bryozoan Membranipora membranacea limits grazing damage by Lacuna vincta on kelp blades. In contrast, a weak positive relationship between grazing damage and bryozoan cover was observed on Saccharina longicruris at an exposed site (Splitnose Point) at low levels of cover (0 to $35 \%$ ). Local degradation of blade tissues under colonies of $M$. membranacea may facilitate grazing by decreasing tissue toughness or polyphenolics (Norderhaug et al. 2003, Molis et al. 2010). No effect of bryozoan cover on grazing damage was observed for Laminaria digitata at this site, or for both Laminaria digitata and $S$. longicruris at a second, more protected site (The Lodge), across a greater range of bryozoan cover. This suggests that even high bryozoan cover does not deter grazing, which is contrary to previous observations (Durante \& Chia 1991, Chavanich \& Harris 2000). Lacuna vincta is capable of grazing through colonies of $M$. membranacea (J. O'Brien, K. A. Krumhansl, R. E. Scheibling unpubl.), incidentally consuming the bryozoan as has been shown for other invertebrates such as sea urchins (van Montfrans et al. 1984, Nestler \& Harris 1994, Meidel \& Scheibling 1999). We occasionally observed $L$. vincta on colonies of $M$. membranacea, particularly in highly degraded parts of the blades.

Peaks in grazing damage of kelps did not correspond to a February peak in abundance of Lacuna vincta recorded in the Gulf of Maine and in Nova Scotia (Johnson \& Mann 1986, Chavanich \& Harris 2002). In contrast, we generally observed peak levels of damage in July and September, when snail density is expected to be at a seasonal low. This discrepancy is likely explained by the prevalence of small snails ( 0 to $2 \mathrm{~mm}$ ) with low grazing rates following recruitment in February (Johnson \& Mann 1986). Larger snails (4 to $10 \mathrm{~mm}$ ) that consume kelp at a faster rate are more prevalent from August to October (Johnson \& Mann 1986), explaining higher damage during these months (Fig. 1D). There were large interannual differences in grazing intensity between September 2008 and 2009 at some sites, possibly due to higher recruitment of $L$. vincta in 2009 than in 2008. 
Between-site variation in grazing damage by Lacuna vincta on each kelp species was explained in part by a negative relationship with site exposure. As we predicted, grazing damage was consistently greater at sites with low and intermediate exposure to waves (Duncan's Cove Protected, Cranberry Cove, The Lodge, and Duncan's Cove Exposed) than the most exposed site (Splitnose Point). Previous studies have found a similar relationship between herbivory and exposure to waves and currents (Duggins et al. 2001, Vanderklift et al. 2009, Taylor \& Schiel 2010), which has been attributed to increased dislodgement from algal substrates or bodily damage to grazers (Menge 1978), or altered foraging behaviour (Kawamata 1998, Lauzon-Guay \& Scheibling 2007) with increased flow. Kelp blade thickness, toughness, and photosynthetic capacity also increase with wave exposure (Kraemer \& Chapman 1991, Wing et al. 2007, Wernberg \& Vanderklift 2010), which may result in greater resilience to herbivory and lower levels of grazing damage. Site exposure also may influence the spatial distribution and rates of settlement and recruitment of $L$. vincta if pre-metamorphic larvae are retained or induced to settle in low-energy environments (Wing et al. 1998, Palma et al. 2006). We also observed a relationship between site exposure and the distribution of grazing damage along blades. Contrary to expectation, the most exposed site - Splitnose Point - appeared to have more concentrated grazing damage in the distal regions of blades than the other sites. This may be because toughness in the distal ends of blades is even more reduced, relative to basal tissues, at high wave exposures, where the ends are damaged by whiplash and abrasion with the substratum.

There was some evidence of a positive relationship between grazing damage and temperature for Saccharina longicruris that is consistent with our prediction, but temperature explained only a small portion of the overall spatial or seasonal variation in grazing damage. The relatively low fit of our models is likely because they were based solely on environmental factors. Direct measures of abundance of Lacuna vincta may explain most of the observed variance in grazing damage.

September peaks in grazing damage to blades by Lacuna vincta are coincident with the seasonal occurrence of hurricanes off Nova Scotia. Results of our field experiment indicate a positive relationship between the extent of grazing damage and blade breakage in Saccharina longicruris under heavy wave conditions generated by a passing hurricane. There was a strong effect of moderate and high levels of simu- lated damage on the rate of blade breakage when a passing hurricane generated a $9 \mathrm{~m}$ spike in significant wave height in Trial 1. In contrast, no effect at any level of simulated damage was detected in Trial 2, despite a passing tropical storm that generated a peak significant wave height of $3.5 \mathrm{~m}$. This suggests a damage threshold (0.5 to $1.0 \%$ loss of blade area) for increased breakage of kelp blades when wave forces also exceed a threshold value (3.5 to $9.0 \mathrm{~m}$ ). Because the level of naturally occurring blade damage exceeds this damage threshold during the summer and fall hurricane season, L. vincta likely contributes to the massive loss of kelp biomass associated with passing hurricanes (authors' pers. obs.), the latter of which occur at a rate of $5.3 \mathrm{yr}^{-1}$ in the Atlantic (Bender et al. 2010).

We have shown that the distribution of damage by Lacuna vincta on kelp blades varies spatially and temporally, likely due to seasonal patterns in growth and the nutritional quality of blade tissue. We did not find a strong relationship between grazing by $L$. vincta and the invasive bryozoan Membranipora membranacea, indicating that the bryozoan does not deter grazing by L. vincta on kelp blades. Spatial variation in the total level of grazing damage was negatively related to site exposure, explaining low levels of grazing damage at highly exposed sites. The direct effects of grazing by L. vincta are relatively small, as area grazed typically represents only a small percentage of the overall blade area (present study) and biomass (Johnson \& Mann 1986). However, we experimentally show that grazing by $L$. vincta can have a large indirect effect on detrital production from kelp beds by increasing rates of kelp blade breakage and erosion (Krumhansl \& Scheibling 2011), especially during large storm events such as hurricanes. This indirect effect may become increasingly important in light of a changing ocean climate, as storms and hurricanes that generate heavy wave conditions increase in frequency and intensity (Bender et al. 2010, Scheibling \& Lauzon-Guay 2010).

Acknowledgements. We thank J. Lindley, L. Sauchyn, S. Watanabe, D. Lyons, V. Burdett Coutts, A. Yorke, M. Saunders, R. Daigle, M. Lloyd, A. McCurdy, T. Wilson, K. Sanford, and A. Ryan for field and lab assistance. We also thank D. Lyons and J-S Lauzon-Guay for statistical advice and comments on earlier drafts of the manuscript, and P. Krumhansl for technical assistance. Three anonymous reviewers also provided useful comments on a previous draft of the manuscript. This research was funded by a Discovery Grant and a Strategic Networks Grant (Canadian Healthy Oceans Network) to R.E.S. from the Natural Sciences and Engineering Research Council (NSERC) of Canada. K.A.K. was supported by a Dalhousie University Scholarship. 


\section{LITERATURE CITED}

Abdullah MI, Fredriksen S (2004) Production, respiration and exudation of dissolved organic matter by the kelp Laminaria hyperborea along the west coast of Norway. J Mar Biol Assoc UK 84:887-894

Anderson DR (2008) Model based inference in the life sciences: a primer on evidence. Springer, New York

Bender MA, Knutson TR, Tuleya RE, Sirutis JJ, Vecchi GA, Garner AT, Held IM (2010) Modeled impact of anthropogenic warming on the frequency of intense Atlantic hurricanes. Science 327:454-458

- Brady-Campbell MM, Campbell DB, Harlin MM (1984) Productivity of kelp (Laminaria spp.) near the southern limit in the Northwestern Atlantic Ocean. Mar Ecol Prog Ser 18:79-88

Brawley S (1992) Mesoherbivores. In: John DM, Hawkins SJ, Price JH (eds) Plant-animal interactions in the marine benthos. Clarendon Press, Oxford, p 235-263

> Bustamante RH, Branch GM, Eekhout S (1995) Maintenance of an exceptional intertidal grazer biomass in South Africa: subsidy by subtidal kelps. Ecology 76:2314-2329

> Chapman ARO, Craigie JS (1977) Seasonal growth in Laminaria longicruris: relations with dissolved inorganic nutrients and internal reserves of nitrogen. Mar Biol 40:197-205

Chavanich S, Harris LG (2000) Potential impact of the introduced bryozoan, Membranipora membranacea, on the subtidal snail, Lacuna vincta, in the Gulf of Maine. In: Pederson J (ed) Marine bioinvasions: proceedings of the first national conference. Massachusetts Institute of Technology, MA, p 157-163

> Chavanich S, Harris LG (2002) The influence of macroalgae on seasonal abundance and feeding preference of a subtidal snail, Lacuna vincta (Montagu) (Littorinidae) in the Gulf of Maine. J Moll Stud 68:73-78

- Chenelot H, Konar B (2007) Lacuna vincta (Mollusca, Neotaeniglossa) herbivory on juvenile and adult Nerocystis luetkeana (Heterokontophyta, Laminariales). Hydrobiologia 583:107-118

> Duggins D, Eckman JE, Siddon CE, Klinger T (2001) Interactive roles of mesograzers and current flow in survival of kelps. Mar Ecol Prog Ser 223:143-155

> Durante KM, Chia F (1991) Epiphytism on Agarum fimbriatum: Can herbivore preferences explain distributions of epiphytic bryozoans? Mar Ecol Prog Ser 77:279-287

Fralick RA, Turgeon KW, Mathieson AC (1974) Destruction of kelp populations by Lacuna vincta (Montagu). Nautilus 88:112-114

Harrold C, Pearse JS (1987) The ecological role of echinoderms in kelp forests. In: Jangoux M, Lawrence JM (eds) Echinoderm studies, Vol 2. A. A. Balkema, Rotterdam, p 137-233

> Hill NA, Pepper AR, Puotinen ML, Hughes MG and others (2010) Quantifying wave exposure in shallow temperate reef systems: applicability of fetch models for predicting algal biodiversity. Mar Ecol Prog Ser 417:83-95

Iyengar EV, Harvell CD (2002) Specificity of cues inducing defensive spines in the bryozoan Membranipora membranacea. Mar Ecol Prog Ser 225:205-218

> Johnson CR, Mann KH (1986) The importance of plant defense abilities to the structure of subtidal seaweed communities: the kelp Laminaria longicruris de la Pylaie survives grazing by the snail Lacuna vincta (Montagu) at high population densities. J Exp Mar Biol Ecol 97:231-267

Kangas P, Autio H, Hällfors G, Luther H, Niemi Å, Salema H
(1982) A general model of the decline of Fucus vesiculosus at Tvärminne, south coast of Finland in 1977-81. Acta Bot Fennica 118:1-27

Kawamata S (1998) Effect of wave-induced oscillatory flow on grazing by a subtidal sea urchin Strongylocentrotus nudus (A-Agassiz). J Exp Mar Biol Ecol 224:31-48

Keddy PA (1982) Quantifying within-lake gradients of wave energy-interrelationships of wave energy, substrate particle-size and shoreline plants in Axe Lake, Ontario. Aquat Bot 14:41-58

Kraemer GP, Chapman DJ (1991) Biomechanics and alginic acid composition during hydrodynamic adaptation by Egregia menziesii (Phaeophyta) juveniles. J Phycol 27: 47-53

Krumhansl K, Scheibling RE (2011) Detrital production in Nova Scotian kelp beds: patterns and processes. Mar Ecol Prog Ser 421:67-82

Krumhansl K, Lee JM, Scheibling RE (2011) Grazing damage and encrustation by an invasive bryozoan reduce the ability of kelps to withstand breakage by waves. J Exp Mar Biol Ecol 407:12-18

- Lauzon-Guay JS, Scheibling RE (2007) Seasonal variation in movement, aggregation and destructive grazing of the green sea urchin (Strongylocentrotus droebachiensis) in relation to wave action and sea temperature. Mar Biol 151:2109-2118

Lawrence JM (1975) On the relationships between marine plants and sea urchins. Oceanogr Mar Biol Annu Rev 13: 213-286

Mann KH (1972) Ecological energetics of the seaweed zone in a marine bay on the Atlantic coast of Canada. II. Productivity of the seaweeds. Mar Biol 14:199-209

- Meidel SK, Scheibling RE (1999) Effects of food type and ration on reproductive maturation and growth of the sea urchin Strongylocentrotus droebachiensis. Mar Biol 134: 155-166

Menge BA (1978) Predation intensity in a rocky intertidal community. Oecologia 34:1-16

Molis M, Enge A, Karsten U (2010) Grazing impact of, and indirect interactions between mesograzers associated with kelp (Laminaria digitata). J Phycol 46:76-84

Nestler EC, Harris LG (1994) The importance of omnivory in Strongylocentrotus droebachiensis (Müller) in the Gulf of Maine. In: David B, Guille A, Féral JP, Roux M (eds) Echinoderms through time. A.A. Balkema, Rotterdam, p 813-818

Norderhaug KM, Fredriksen S, Nygaard K (2003) Trophic importance of Laminaria hyperborea to kelp forest consumers and the importance of bacterial degradation to food quality. Mar Ecol Prog Ser 255:135-144

> Palma AT, Pardo LM, Veas R, Cartes C and others (2006) Coastal brachyuran decapods: settlement and recruitment under contrasting coastal geometry conditions. Mar Ecol Prog Ser 316:139-153

> Robertson AI, Lucas JS (1983) Food choice, feeding rates and the turnover of macrophyte biomass by a surf-zone inhabiting amphipod. J Exp Mar Biol Ecol 72:99-124

Robles C, Robb J (1993) Varied carnivore effects and the prevalence of intertidal algal turfs. J Exp Mar Biol Ecol 166:65-91

> Rothäusler E, Gomez I, Hinojosa IA, Karsten U, Tala F, Thiel $M$ (2009) Effect of temperature and grazing on growth and reproduction of floating Macrocystis spp. (Phaeophyceae) along a latitudinal gradient. J Phycol 45:547-559

Scheibling RE, Gagnon P (2009) Temperature-mediated out- 
break dynamics of the invasive bryozoan Membranipora membranacea in Nova Scotian kelp beds. Mar Ecol Prog Ser 390:1-13

Scheibling RE, Lauzon-Guay JS (2010) Killer storms: North Atlantic hurricanes and disease outbreaks. Limnol Oceanogr 55:2331-2338

Scheibling RE, Kelly NE, Raymond BG (2009) Herbivory and community organization on a subtidal cobble bed. Mar Ecol Prog Ser 382:113-128

Sjotun K, Fredriksen S, Rueness J (1996) Seasonal growth and carbon and nitrogen content in canopy and first-year plants of Laminaria hyperborea (Laminariales, Phaeophyceae). Phycologia 35:1-8

Taylor DI, Schiel DR (2010) Algal populations controlled by fish herbivory across a wave exposure gradient on southern temperate shores. Ecology 91:201-211

Underwood AJ (1997) Experiments in ecology: their logical design and interpretation using analysis of variance. Cambridge University Press, Cambridge, UK

> van den Poel D, Lariviere B (2004) Customer attrition analysis for financial services using proportional hazard models. Eur J Oper Res 157:196-217

Editorial responsibility: Riccardo Cattaneo-Vietti, Genova, Italy van Montfrans J, Wetzel RL, Orth RJ (1984) Epiphyte-grazer relationships in seagrass meadows: consequences for seagrass growth and production. Estuaries 7:289-309

Vanderklift MA, Lavery PS, Waddington KI (2009) Intensity of herbivory on kelp by fish and sea urchins differs between inshore and offshore reefs. Mar Ecol Prog Ser 376: 203-211

Vetter EW (1995) Detritus-based patches of high secondary production in the nearshore benthos. Mar Ecol Prog Ser 120:251-262

Wernberg T, Vanderklift MA (2010) Contribution of temporal and spatial components to morphological variation in the kelp Ecklonia (Laminariales). J Phycol 46:153-161

Wing SR, Botsford LW, Ralston SV, Largier JL (1998) Meroplanktonic distribution and circulation in a coastal retention zone of the northern California upwelling system. Limnol Oceanogr 43:1710-1721

> Wing SR, Leichter JJ, Perrin C, Rutger SM, Bowman MH, Cornelisen CD (2007) Topographic shading and wave exposure influence morphology and ecophysiology of Ecklonia radiata (C. Agardh 1817) in Fiordland, New Zealand. Limnol Oceanogr 52:1853-1864

Submitted: March 9, 2011; Accepted: July 7, 2011

Proofs received from author(s): August 25, 2011 